Vol. XXIII No $1 \quad 2017$

\title{
DEPLOYABILITY OF ARMED FORCES IN THE CURRENT ARMED CONFLICTS
}

\section{Ivan MAJCHÚT}

\author{
Armed Forces Academy of General Milan Rastislav Štefánik, Liptovský Mikuláš, \\ Slovakia \\ ivan.majchut@aos.sk
}

\begin{abstract}
Achieving victory in nowadays armed conflicts by using of conventional military forces seems more and more difficult. Military solutions are not satisfying and used civilian-military effort still needs many improvements. So-called irregular warfare requires more regular or conventional capabilities than is usually necessary to win in regular warfare. The question is how to adapt armed forces for the nowadays irregular environment. How to educate, train and deploy armed forces? How to create a reliable tool of military power for using in irregular warfare?
\end{abstract}

\section{Keywords: Capabilities, conventional warfare, irregular warfare}

\section{Introduction}

Many experts on the employment of military force warn about the contemporary problems of education, training and deployment of military forces. If military force should be used for some political reasons to resolve the crisis, whether at the beginning or during it, the question is how to implement it.

The essence of the debate in the military coalition is to define the position in the spectrum of conflict and to determine the character of the military operation. Next step is, to appoint the concept of realisation of meaning operation with the effort to meet defined military objectives and thereby creating the conditions for achieving political goals.

It is expected that the use of military force (and other tools to solve the present crisis) will be credible to the population of the affected countries; it means those who are to be supported. At the same time, it is expected that the use of the military force will be credible to the population of the countries from which deployed forces are posted.

\section{The character of war}

Politicians and soldiers often make considerable efforts to name a war and to characterize its various aspects. Many different ideas and understandings are presented in this process. The initial effort to create a fruitful discussion to determined topic the establishment is lost in a military mental obsession to establish the definition, traceability and clear delimitation of each activity.

Military warfare is in its extreme forms, process-oriented. Standard operating procedures (SOPs) are creating and what is not specified and explained in them it is managed quite difficult. Unfortunately, sometimes their processing caused more frictions than the actual military art.

The effort to define the particular war (conventional, traditional, regular, irregular, hybrid ...) and the effort to assign the particular form of warfare (regular or irregular) is developing the discussion about the capabilities creation. The need for a comprehensive understanding of the power struggle as the cause of the war and 
subsequently warfare is sometimes forgotten. Independent variables (emotions, chance, and a reason), which vary in every war, and new technological improvements have great effect upon the character of war. They affect the tactics, operational art, military strategy and in some cases even grand strategy of respective actors. It is now apparent that character of war is changing. [4]

Aspects of the power struggle are connected to each other. No matter you have used uniformed (military) personnel or personnel without uniform. Civil power elite use various methods, means and tools against the opponent depending on what is going on. If it is necessary they use activities of uniformed personnel, or it is without military involvement. They will even do it secretly, without regard to belonging to "East" or "West".

Collision in the understanding of political activities and also military warfare occurs when irregular warfare is analysed in the same one-dimensional way like conventional warfare. The collision is much bigger when to the process are included secret activities, what is the usual way of irregular warfare conducting.

It might be counterproductive to study, plan and actively wage the war with specifying war as a regular or irregular. More important is, how the armed forces will be created for to be the tool in all aspects of war and power struggles.

If the power struggle is not in the form state vs. state, it is necessary to seek limits on conventional warfare applications and to determine aspects which are needed to change. Actors of the power struggle will do it always. If they are unable to create conventional military forces, they will fight in secret and hidden, armed depending on the situation. The context of war is all around us, but absolutely military wars are rare and very rarely with the full deployment of all equipment. There is still power struggle and there are still different kinds of wars existing. No matter how we will mark the "war". Question is, what missions to specify for armed forces and what capabilities to build up for the fulfilment of the tasks. This issue is gaining in importance when many forms of non-military tasks are needed and necessity of close connection between military and civilian elements deployed to achieve the power struggle objectives is expected.

The $20^{\text {th }}$ century, focusing on the major wars, thrive generation of military experts and politicians with a single-valued view at the military forces. The tool of military force was theoretically prepared and many times in real life "tested". Today, the same generation (as well as the new one) is facing the irregular warfare.

Yesterday's educational and training options were flipped to the present situation with limited educational background and increasing necessity for practical implementation. [2]

\section{The character of military operation}

Current military operations may be in accordance with the Alliance doctrines [1] classified into four basic categories:

- Combat (Operations to Neutralise Major Threats),

- Security (Operations to Enable Stabilization),

- Peace Support Operations,

- Other Activities.

Both world wars (but also the cold war) supported the way of thinking and preparation for war in long term. The basic reason for the existence of the armed forces was mainly the existence of so-called great wars. Willingness and even the possibility of military institutions to think outside of conventional warfare were very limited. That matches the structure and training of armed forces in a substantial part of the "western" and also "eastern" countries. In nowadays terms of military operations, armed forces have been preparing for the combat (operations to neutralise major threats). But today's military operations are often conducted in a challenging context of 
irregular warfare (operations to enable stabilization and peace support operations).

The states have lost their monopoly to conduct armed conflict and one of the parties to the conflict is often represented by an aggressive non-state actor. The tactics of nonstate actors belong to the category of asymmetric warfare. The asymmetry in military point of view is confronting activities carried out in accordance with military standards and international law vs. various methods of guerrilla warfare, when they ignore Geneva Conventions. [6]

Armed forces are supposed to be also successful in non-combat operations, where the armed forces are used, for example, in reestablishing of government authorities, providing basic services for local population as well as in assistance tasks supporting security and rescue organizations. [9]

Conventional military forces were not thrilled by deploying in operations to enable stabilization and peace support operations. For example, involvement in counterinsurgency was something very difficult for them.

"Real fighters" do not want to deal with socalled small wars. [3] Conventional war and conventional warfare have, in many military systems all over the world, very rich theoretical basis. Comparing to the irregular warfare, there is fundamentally negative attitude. This fact creates basic obstacle for armed forces to adapt themselves for postmodern military operations. The military academic community often focuses the research on great wars and theoretical bases of small wars are insufficient. This causes complications in the creation of the modern military thinking.

Membership in multinational coalitions mentioned problem more escalates. Different national approaches and concerns, the absence of common doctrine or its different perception, different level of training cause fragmentation of joint effort. In addition, many operations start as a conventional war and later they are changing to the phase of stabilization. Essentially, the same unit provides combat and it is used in non-combat counterinsurgency, which is a difficult matter. Frequent security activities, carried out by outsourcing companies, complicate formation of fundamental links with people living in the affected region and gaining their trust. In addition, a large number of civilian nongovernmental organizations and various private organizations refuse cooperation with military forces. The problem of achieving a comprehensive approach of military and civilian activities of various sources is well known and it causes a problem of "multifunctional coordination".

Conventional warfare (within the military dimension) requires particular capabilities, which however are not the same for operations to enable stabilization and peace support operations. We are talking about regular and irregular warfare, and both are needed different capabilities. The same unit rarely achieves such a wide range of capabilities. Operational planning and decision-making processes were originally designed for conventional warfare between the armed forces. They were not designed for "working" with various types of insurgents, rebels, terrorists, criminal formations and fully mercenary forces, supported by various nations or structures. In addition, the situation is complicated when the troops, commanders and staff personnel are rotated every $6-12$ months.

Now, we are not interested only in sensor and shooter on the opposite side. We are interested in the comprehensive deployment of "boots on the ground" and winning "hearts and minds". This hybrid and mainly irregular war is guided by people and between people. [5] Finding new ways of success against irregular opponents, it creates a problem of the scale and impact to the military system. Irregular warfare is more about ideas than about physical targets. Covert methods and means of influencing the opponent are as interesting as the use of brute armed force. [8]

These challenges are not only strategic but also operational, and tactical. They are really multi-dimensional. The issues affect personnel, thinking, options, operational art, 
and tactics, doctrines, education and training, the mentality of military conventional fighter versus mentality of "peacemaker", leadership, and potential for full-conceptual employment and therefore the usefulness of military force.

Training and deployment of troops in irregular warfare require a change in military thinking, especially in operational art and tactics. It is necessary:

- Define the needed capabilities and military instruments for current and future operations in irregular warfare,

- Clearly formulate the concept of the armed forces transformation,

- Prepare a long-term plan for education of military and political generations,

- At the same time, prepare a short-term, realistic transformation of training, capabilities, operational art and tactics, doctrines and concepts development.

But the creation of the armed forces, deployable in irregular warfare, mays not causes the loss of basic capabilities in conventional warfare.

\section{The character of irregular warfare}

The military viewpoint of the current irregular warfare is fundamentally influenced by the concept of the United States. It affects the concept of the NATO and the EU countries (if they have any concept).

Mentioned countries and organizations are trying to manage "todays" and "tomorrows" requirements for their armed forces. These forces should seek ability of "expeditionary" deployment. The focus should be placed on the ability to operate abroad for a long time and multinational. "Expeditionary" profile is also required as an essential parameter for relevant civilian agencies and state functionalities which are expected operate side by side with military functions. Military function is important but not the only tool used in operations to enable stabilization and peace support operations

Multinational coalition force, deployable to operations in the irregular environment, must be multifunctional in capabilities, although it is not clear how to achieve it. Mentioned capabilities must be much more "miscible" and more universal in the military as well as in civilian point of view, especially if it is about capabilities for operations to enable stabilization.

Solving conflicts and crises in contemporary operational environment indicates that military force, as long as activities of other nation's power instruments are insufficient, remains the most decisive, quickest and the most effective element for accomplishing the strategic political and military objectives, and (though not always) establishing the conditions necessary to achieve desired end state. [7]

Deployed forces, it is not only the deployment of armed (military) forces. This category can also include the Special Forces, police and intelligence structures with a large scale of tools. The exact meaning of what tool is possible to use for what raises a number of questions. The question is what instruments should be built by countries separately and what together. The interplay in coalition operations is important. The age-old problem for traditional military force is the space of unconventional warfare. It is not clear how the competencies of the military, police on the one hand and other government special activities on the other hand are defined. [8] One thing is what it means to handle the context of irregular warfare and another thing is what share of it will be civilian and military matter. Activities in power struggle belong to three areas:

- The use of political/diplomatic tools,

- The realization of intelligence/special operations,

- The deployment of the armed forces.

A classical power struggle with the use of foreign affairs, intelligence with hidden activities and uniformed military services is reflected in this hierarchy. 


\section{Conclusions}

Military irregular warfare is multidimensional. The core of the problem lies in the limited theoretical apparatus and in the traditional military approach to this form of war. Repeated experiences, connected with military effort in an irregular environment all over the world, were often neglected.

Comprehensive use of civilian and military instruments or the creations of new "complex units" under civilian command/control are encouraged. Research, theory, doctrine and obtained experiences are vital pillars. If not, the way to the capabilities for irregular warfare will be still as problematic as it is today.

The decision about the scope of the military instruments and thereby also about their development rests in the hands of politicians. The future of military capabilities for irregular warfare also rests in the hands and minds of military system members, especially members of the military academic environment. If neither of these groups recognizes the needs of unconventional war and warfare, more and more people will die and more and more hearts and minds will be lost.

\section{References}

[1] AJP-01(D): Allied Joint Doctrine. Brussels : NSA, 2010. 130 p. [Cit. 2017-03-02]. Available at: https://www.gov.uk/government/uploads/system/uploads/attachment_data/ file/33694/AJP01D.pdf

[2] KELEMEN, Miroslav, ANDRASSY, Vladimír: Use of simulation in actual preparing of armed forces for military emergencies and non-military emergencies (in Slovak), Využívanie simulácie $\mathrm{v}$ príprave súčasných ozbrojených síl pre krízové situácie vojenského a nevojenského charakteru. In: Bezpieczeństwo - ujęcie kompleksowe. Katowice : Wyższa Szkoła Zarządzania Marketingowego i Języków Obcych w Katowicach, 2012, ISBN 978-83-87296-24-7, p. 253-262.

[2] NAGL, A. John: Learning to Eat Soup with a Knife, Counterinsurgensy Lessons from Malaya and Vietnam. Westport : Praeger Publishers, 2002, ISBN 0-275-97695-5, 250 p.

[3] PIKNER, Ivo, ŽILINČÍK Samuel: Military concepts and hybrid war. In: Forum Scientiae Oeconomia. Volume 4 (2016) Special Issue No. 1 : Security management: local, regional and global perspectives. Dąbrowa Górnicza : Wyższa Szkoła Biznesu w Dąbrowie Górniczej, 2016, ISSN 2300-5947, p. 25-34.

[4] SMITH, Rupert: The Utility of Force. New York : Vintage books, 2007, ISBN 978-0307-27811-1, $430 \mathrm{p}$.

[5] SPILÝ, Peter, HRNČIAR, Michal: Military tactics (in Slovak), Vojenská taktika. Liptovský Mikuláš : Armed Forces Academy of gen. Milan Rastislav Štefánik, 2013, ISBN 978-80-8040-471-0, 274 p.

[6] SPIŠÁK Ján: Operational Thinking and its Application in Operational Design. In: The 22th International Conference The Knowledge-Based Organization MANAGEMENT AND MILITARY SCIENCES. Sibiu : NICOLAE BĂLCESCU" LAND FORCES ACADEMY, 2016, ISSN 1843-682X, p. 142 - 147.

[7] US DoD: Irregular Warfare (IW) Joint Operating Concept (JOC). Washington: 2007. 100 p. [Cit. 2017-03-02]. Available at: https://fas.org/irp/doddir/dod/iw-joc.pdf

[8] VARECHA, Jaroslav: Possible view on the combat potential parameters (in Slovak), Možný pohl'ad na parametre bojového potenciálu. In: National and International Security 2016: $6^{\text {th }}$ international science conference. - Liptovský Mikuláš : Armed Forces Academy of gen. Milan Rastislav Štefánik, 2016, ISBN 978-80-8040-534-2, pp. 569 - 577. 